\title{
Beta Adrenergic Receptors Stimulation Attenuates Phosphorylation of NF-kB and IKB $\alpha$ in Hyperglycemic Endothelial Cells
}

\author{
Sher Zaman Safi ${ }^{a, b} \quad$ Humaira Shah ${ }^{d} \quad$ Rajes Qvist $^{b} \quad$ Priyadarshni Bindale $^{\mathrm{a}}$ \\ Marzida Mansor ${ }^{c}$ Gracie Ong Siok Yanc ${ }^{c}$ Ikram Shah Bin Ismail ${ }^{b}$ \\ aInterdisciplinary Research Center in Biomedical Materials (IRCBM), COMSATS University Islamabad, \\ Lahore Campus, Lahore, Pakistan, 'bepartment of Medicine, Faculty of Medicine, University of Malaya, \\ Kuala Lumpur, 'Departments of Anaesthesiology, Faculty of Medicine, University of Malaya, Kuala \\ Lumpur, Malaysia, 'Department of Zoology - University of the Punjab, Lahore, Pakistan, eSchool of \\ Health Sciences University of Tasmania, Newnham, Australia
}

\section{Key Words}

Beta Adrenergic receptors - Hyperglycemia-induced inflammation - Apoptosis - NF-kB • HUVECS

\begin{abstract}
Background/Aims: NF- $\mathrm{KB}$ induces transcription of a number of genes, associated with inflammation and apoptosis. In this study, we have investigated the effect of $\beta$-adrenergic receptor stimulation on NF- $\mathrm{kB}$ and $\mathrm{I} \mathrm{kB} \alpha$ in HUVECs. Methods: Human umbilical vein endothelial cells (HUVECs) were cultured in high and low glucose concentrations. All HUVECs were treated with different concentrations of isoproterenol and propranolol for different time periods. The analytical procedures consisted of Western Blot, ELISA, DCFH-DA and TUNEL assays. Results: Isoproterenol (agonist of a beta-adrenergic receptor) significantly reduced phosphorylation at Ser-536 of NF-kB; and Ser-32 and Ser-36 of IKB $\alpha$ in hyperglycemic HUVECs. Isoproterenol also significantly reduced apoptosis and ROS generation. No effect of $\mathrm{IkB} \alpha$ was observed on Tyr-42 phosphorylation. The effect of isoproterenol was reversed by the antagonist propranolol. We also checked if NF-KB inhibitor MG132 causes any change at the level of apoptosis. However, we observed an almost similar effect. Conclusion: Given data demonstrates that beta-adrenergic receptors stimulation has a protective effect on HUVECs that might be occuring via NF- $\kappa \beta$ and $I \kappa B \alpha$ pathway.

(C) 2018 The Author(s) Published by S. Karger AG, Basel

\section{Introduction}

Diabetes mellitus (DM) is considered to be a metabolic disorder characterized by hyperglycaemia, insulin resistance, pancreatic $\beta$ cell dysfunction and other complications [1-10]. Worldwide, millions of people are being affected by diabetes, assigning it as one

Dr. Sher Zaman Safi and Dr. Ikram Shah Bin Ismail

Interdisciplinary Research Centre in Biomedical Materials (IRCBM), COMSATS University Islamabad, Lahore Campus (Pakistan); Department of Medicine, Faculty of Medicine, University of Malaya, 50603 Kuala Lumpur (Malaysia),E-Mail safi.nust@yahoo.com; ikram@ummc.edu.my
\end{abstract}




\section{Cellular Physiology Cell Physiol Biochem 2018;51:1429-1436 and Biochemistry Published online:28 November $2018 \mid \begin{aligned} & \text { @ } 2018 \text { The Author(s). Published by S. Karger AG, Basel } \\ & \text { wOr.com/cpb }\end{aligned}$ \\ Safi et al.: Beta-AR Stimulation and Phosphorylation of NF-kB and Ikb'B $\alpha$}

of the most common non-communicable diseases [8-10]. The molecular and biochemical mechanisms of both type I Diabetes mellitus (T1DM) and type II Diabetes mellitus (T2DM) are not necessarily be the same. However, there are numerous common similarities between both. Both types of diabetes greatly increase the risk of various other complications including inflammation and endothelial dysfunction [10-16].

Overproduction of reactive oxygen species (ROS) by mitochondria is known to be a causal link between hyperglycemia and the major biochemical pathways, including NFkB-mediated inflammation $[17,18]$. NF- $\kappa \beta$ pathway is a well known pro-inflammatory signalling pathway [19]. NF- $\kappa \beta$ is a transcription factor that regulates the $\kappa \beta$ light chain expression and also regulates the genes that control cell survival and cell proliferation [19]. Studies have shown that the activation of NF- $\kappa \beta$ pathway plays an essential role in apoptosis, inflammatory responses, cellular growth and developmental processes [20]. Upon cellular

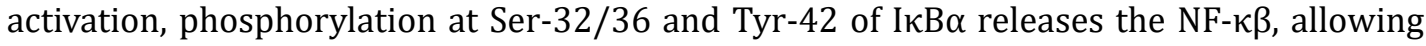
it to translocate to the nucleus where it acts as a transcription factor and up-regulates the expression of numerous pro-inflammatory genes, including cytokines and adhesion molecules [21]. Phosphorylation of NF- $\kappa \beta$ p65 occurs on several serine residues. Upon treatment with TNF $\alpha$, Ser-529 is phosphorylated by casein kinase II [22, 23], Ser-311 by protein kinase C (PKC) [24], Ser-276 by both PKA and mitogen- and stress-activated protein kinase 1 (MSK1) [25, 26] and Ser-536 by the IкB kinase (IKK) complex [27] in a range of cell types.

Beta-adrenergicreceptors are the emergingtargets for seeking therapeutic interventions. Several studies have suggested that they might be the promising targets against vascular, cardiac and metabolic complications. In a study, isoproterenol treatment significantly decreased protein levels of iNOS, TNF- $\alpha$, and IL-1B, in rMC-1 cells [28]. Stimulation of beta2 adrenergic receptor also exhibited anti-inflammatory effects in rats [29]. The aim of this study was to analyse the effect of isoproterenol ( $\beta$-ARs agonist) and propranolol ( $\beta$-ARs antagonist) on the hyperglycemia-induced apoptosis and phosphorylation of NF- $\kappa B$ at Ser536 and $\mathrm{I} \kappa \mathrm{B} \alpha$ at Ser-32, Ser-36 and Tyr-42 in HUVECs.

\section{Materials and Methods}

\section{Cell Culture}

Human umbilical vein endothelial cells (HUVECs) were cultured in complete ECM media, supplemented with 10\% FBS, 1\% Penicillin-Streptomycin and animal-derived growth factors. Cells were cultured in flasks containing normal (5 mM) and high $(25 \mathrm{mM})$ glucose. HUVECs were treated with agonist (isoproterenol) and antagonist (propranolol) in $5 \mu \mathrm{M}, 10 \mu \mathrm{M}$ and $20 \mu \mathrm{M}$ concentrations for 6,12 and 24 hours. Cells were also treated with TNF- $\alpha(10 \mathrm{ng} / \mathrm{ml})$. Cells were grown in $5 \% \mathrm{CO}^{2}$ at $37^{\circ} \mathrm{C}$. Media was changed every 2 to 3 days.

\section{Western Blot Analysis}

HUVECs were lysed, centrifuged and proteins were extracted according to the manufacturer's protocol (Sigma). Total of $30 \mu \mathrm{g}$ proteins was loaded in each well and separated on 10\% SDS-PAGE (Precast gels, Bio-Rad, cat no 456-1093). Blots were incubated overnight at $4^{\circ} \mathrm{C}$ with primary antibodies (1:3000) against I $\kappa \mathrm{B} \alpha$ and NF- $\kappa \mathrm{B}$ (Santa Cruz). Anti- $\beta$-actin (Santa Cruz, sc-7210) antibodies were used to ensure the quality of protein separation and loading contents. Membranes were incubated with HRP-conjugated IgG secondary antibodies (Santa Cruz, sc-2004) and visualized with enhanced chemiluminescence (Amersham Life Sciences, UK), using gel imaging system (Biospectrum 410, UVP).

Terminal deoxynucleotidyl transferase dUTP nick end labelling (TUNEL) assay

DNA damage was examined and quantified, using a colorimetric apoptosis detection kit with TUNEL staining in a 96-well format (Titer TACS; R\&D System). Briefly, $1 \times 10^{5}$ cells/well were transferred into a 


\section{Cellular Physiology Cell Physiol Biochem 2018;51:1429-1436

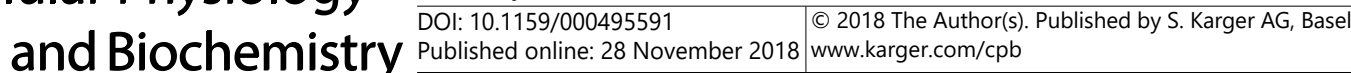 \\ Safi et al.: Beta-AR Stimulation and Phosphorylation of NF-kB and Ikb'B $\alpha$}

96-well plate and fixed with 3.7\% buffered formaldehyde for 5 minutes. After washing with PBS, cells were subjected to permeabilization with $100 \%$ methanol for 20 minutes. Labelling procedure was carried out and the reaction was stopped with $0.2 \mathrm{~N} \mathrm{HCl}$. The absorbance was measured at $450 \mathrm{~nm}$ with a microplate reader.

Dichloro-dihydro-fluorescein diacetate (DCFH-DA) assay

$2^{\prime} 7^{\prime}$-dichloro-dihydro-fluorescein diacetate (DCFH-DA) reagent was used to measure intracellular ROS (reactive oxygen species). Cells were seeded in 96-well plates for 24 hours with beta adrenergic receptors agonist and antagonist. Cells were then treated with $5 \mu \mathrm{M}$ DCFH-DA and the readings were taken at $485 \mathrm{~nm}$ excitation and $530 \mathrm{~nm}$ emission in a fluorescence plate reader.

\section{Statistical Analysis}

Each test was performed in triplicate. The results were expressed as the mean value \pm SD. One-way ANOVA test was used to determine statistical significance. A value of 0.05 was considered significant. Statistical analysis was performed using SPSS-17.0 package (IBM Corporation, Armonk, NY, USA).

\section{Results}

Effect of beta-adrenergic receptors agonist and antagonist on apoptosis in HUVECs

We investigated the effect of isoproterenol (beta-adrenergic receptors agonist) and Propranolol (beta-adrenergic receptor antagonist) on HUVECs. TUNEL assay was employed to check the apoptosis. Cells treated with higher glucose concentration for 24 hours showed significantly high apoptosis. Isoproterenol at various concentrations significantly reduced the level of apoptosis. Isoproterenol at concentrations of $10 \mu \mathrm{M}$ and $20 \mu \mathrm{M}$ for 12 hours; and $5 \mu \mathrm{M}, 10 \mu \mathrm{M}$ and $20 \mu \mathrm{M}$ for 24 hours (Fig. 1A, 1B and 1C) showed a significant effect on hyperglycemia-induced apoptosis. No effect was observed at 6 hours' time period. Propranolol reversed the effect of isoproterenol when treated with $10 \mu \mathrm{M}$ and $20 \mu \mathrm{M}$ for 12 hours and 24 hours respectively.

Effect of beta-adrenergic receptors agonist and antagonist on reactive oxygen species (ROS)

Studies have reported that hyperglycemia significantly induces the level of reactive oxygen species in endothelial cells. We were keen to investigated the process by which betaadrenergic receptors agonist and antagonists alter ROS level. As shown in Fig. 1D and 1E, high glucose-treated cells showed high ROS generation. Isoproterenol at concentrations of $5 \mu \mathrm{M}, 10 \mu \mathrm{M}$ and $20 \mu \mathrm{M}$ for 6 hours, 12 hours and 24 hours, reduced ROS generation in hyperglycemic HUVECs. We observed a significant effect when isoproterenol was treated at a concentration of $20 \mu \mathrm{M}$ for 24 hours. Propranolol reversed the effect of isoproterenol.

Stimulation of Beta-adrenergic receptors attenuates apoptosis and ROS via NF- $\kappa B$ and I $\kappa \alpha$ pathway

To elucidate the mechanisms underlying the observed reduction in apoptosis (Fig. 1A, $1 B, 1 C$ ) and ROS generation (Fig. 1D) with increased cells viability, we examined NF- $\kappa B$ pathway. As shown in Fig. 2A and 2B, glucose stimulation induced phosphorylation of p65 at Ser-536. Cells were then subjected to various concentrations of agonist (isoproterenol) and antagonist (propranolol) for 24 hours. There was a significant reduction in the level of phosphorylation of NF- $\mathrm{kB}$ p65 at Ser-536 upon isoproterenol treatment at a concentration of $10 \mu \mathrm{M}$ and $20 \mu \mathrm{M}$ for 24 hours. Propranolol showed a reversed effect against isoproterenolinduced effect at a concentration of $10 \mu \mathrm{M}$ and $20 \mu \mathrm{M}$ for 24 hours.

Eukaryotic cells utilise NF-kB as a regulator of genes that control cell survival and proliferation. To test our hypothesis and to further elucidate the effect of beta-adrenergic receptor stimulation, we intended to first enhance the phosphorylation level and then use isoproterenol and propranolol to see whether high phosphorylation level could be 


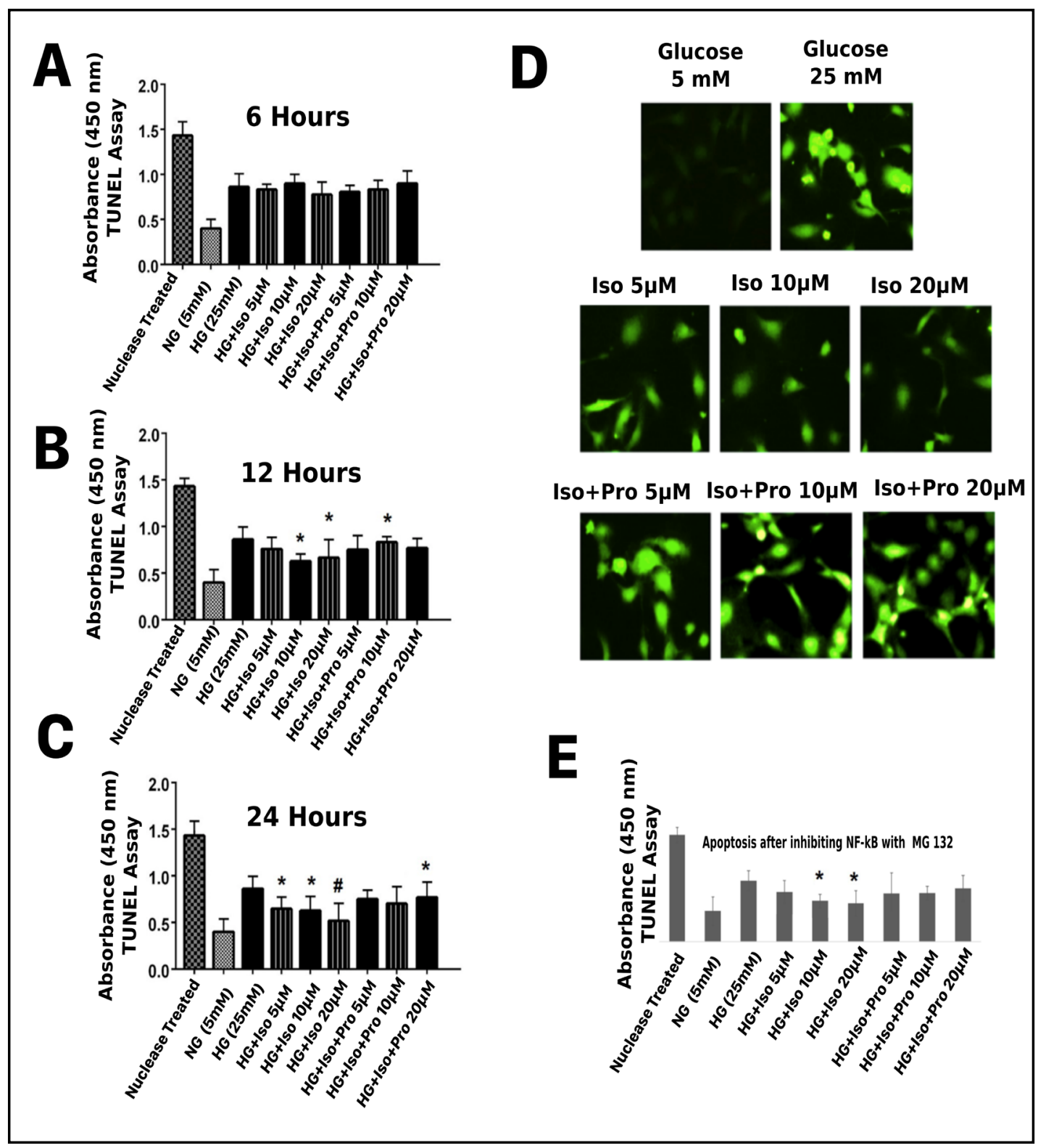

Fig. 1. Effect of isoproterenol on apoptosis and ROS generation. This Fig. shows increases apoptosis in human umbilical vein endothelial cells, treated with high glucose. Apoptosis was reduced by isoproterenol (showed iso in labelling) at different concentrations (5 uM, $10 \mathrm{uM}$ and $20 \mathrm{uM}$ ) and time periods 6 hours (1A), 12 hours (1B) and 24 hours (1C). ROS generation was also reduced after isoproterenol treatment (1D). This effect was diminished by the antagonist of beta-adrenergic receptor propranolol (showed pro in labelling). Fig. 1E shows the level of apoptosis after inhibiting NF- $\kappa B$ with MG 132.

reduced. Cells were subjected to TNF- $\alpha(10 \mathrm{ng} / \mathrm{ml})$ for 24 hours. Enhanced phosphorylation of NF- $\kappa$ B p65 at Ser-536 after TNF- $\alpha$ treatment was observed. Isoproterenol treatment at a concentration of $5 \mu \mathrm{M}, 10 \mu \mathrm{M}$ and $20 \mu \mathrm{M}$ for 24 hours significantly reduced the TNF- $\alpha$ induced phosphorylation of NF- $\kappa$ B p65 at Ser-536 (Fig. 2C and 2D). Propranolol diminished the effect of isoproterenol.

It is evident that IKKb can increase phosphorylation of p65 Ser-536, as well as Ser-32

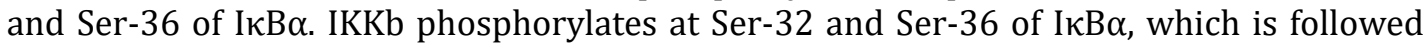
by the release of NF- $\kappa B$ from its inhibitor and consequently its activation. Based on these reported mechanisms, we presumed that the de-phosphorylation of NF-kB at Ser-536 is 


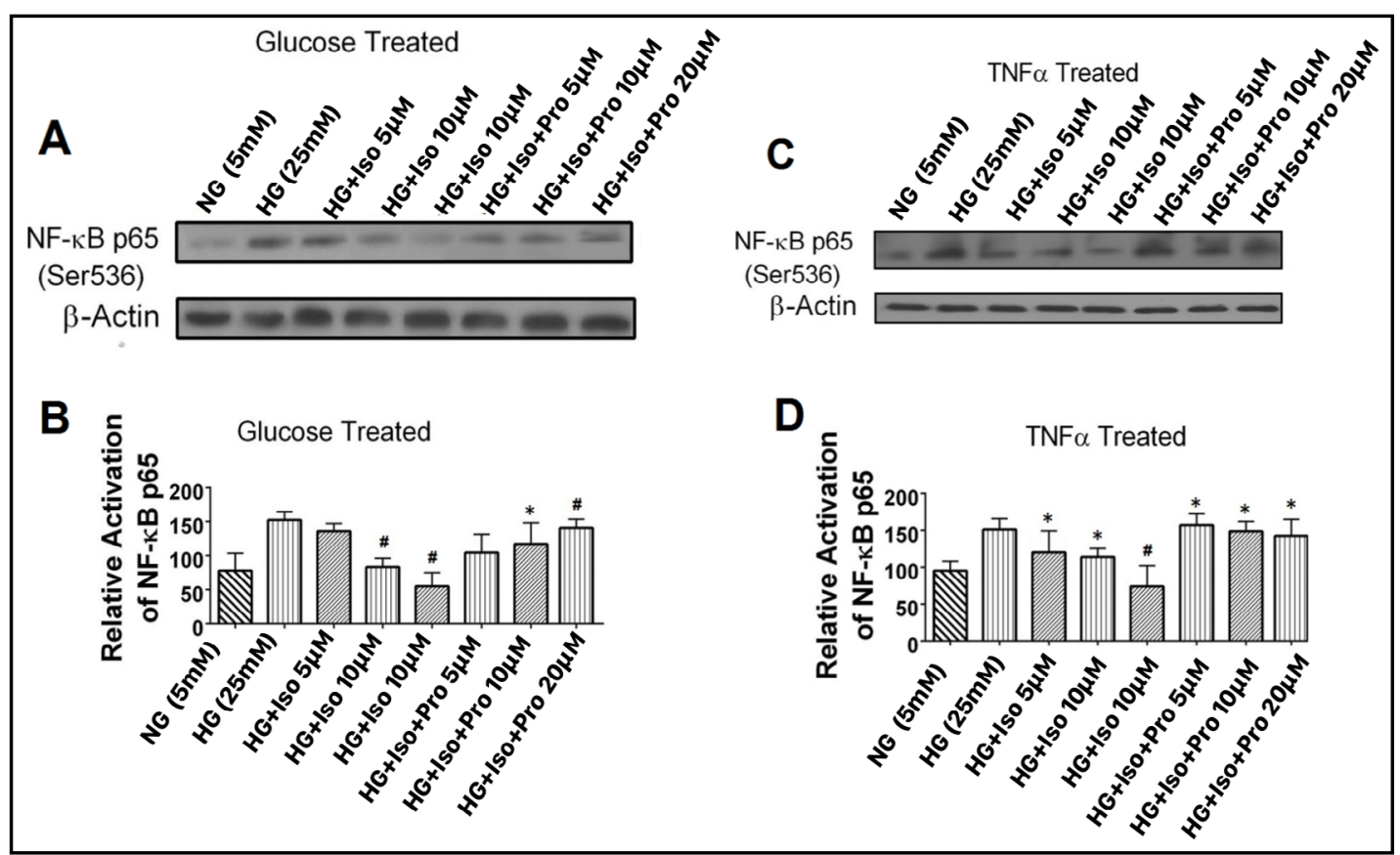

Fig. 2. Phosphorylation of NF- $\kappa B$. This Fig. demonstrates the effect of isoproterenol and propranolol on glucose (2A, 2B) and TNF- $\alpha$ induced (2C, 2D) phosphorylation of NF- $\kappa B$ p65 at Ser-536 in HUVECs. High glucose and TNF- $\alpha$ treated cells showed increased phosphorylation of NF- $\kappa B$ p65 at Ser-536 which was significantly reduced by isoproterenol. The effect of isoproterenol was reversed by the agonist propranolol.

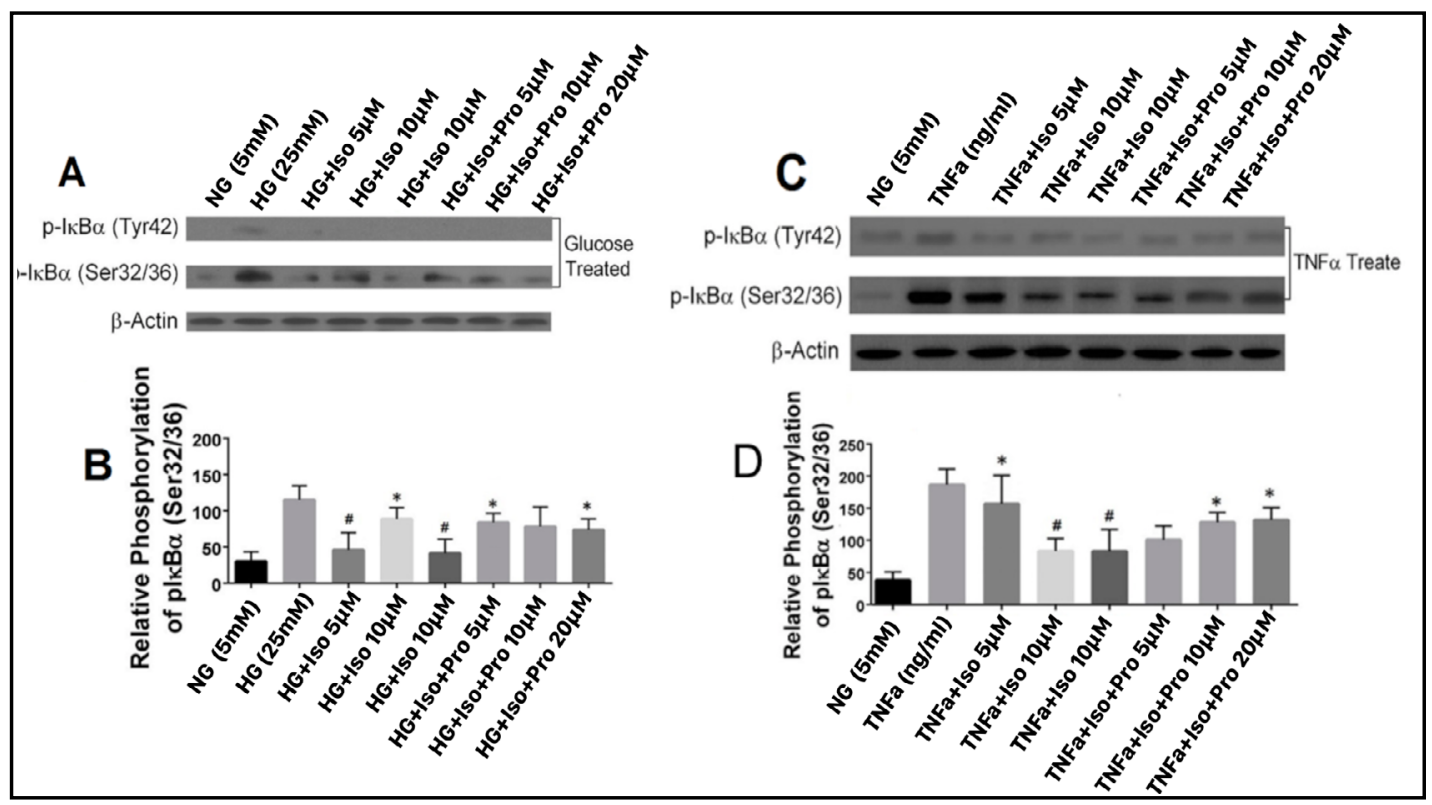

Fig. 3. phosphorylation of IкB $\alpha$ at Ser-32, Ser-36 and Tyr-42. This Fig. shows the effect of isoproterenol and propranolol on glucose (3A, 3B) and TNF- $\alpha$ induced (3C, 3D) phosphorylation of IкB $\alpha$ at Ser-32, Ser-36 and

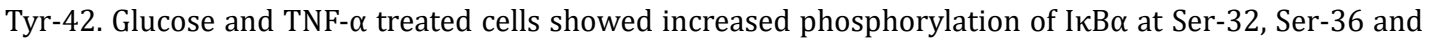
Tyr-42 which was significantly reduced by isoproterenol. The effect of isoproterenol was reversed by the agonist propranolol.

actually due to the de-phosphorylation of IкB $\alpha$. To confirm this hypothesis, we further studied phosphorylation at Ser-32, Ser-36 and Tyr-42 of IкB $\alpha$. Interestingly, exposure to glucose increased the phosphorylation of IKB $\alpha$ at Ser-32 and Ser-36 with no effect on Tyr-42 (Fig. 


\section{Cellular Physiology Cell Physiol Biochem 2018;51:1429-1436 and Biochemistry \begin{tabular}{c|c|c|} 
DOl: 10.1159/000495591 & Published online:28 November 2018 www.karger.com/cpb
\end{tabular} \\ Safi et al.: Beta-AR Stimulation and Phosphorylation of NF-kB and Ikb'B $\alpha$}

3A and 3B). Isoproterenol at concentrations of $5 \mu \mathrm{M}, 10 \mu \mathrm{M}$ and $20 \mu \mathrm{M}$, significantly reduced the glucose-induced phosphorylation of Ser-32 and Ser-36. The effect of isoproterenol was validated by propranolol at the same concentrations and time periods. HUVECs were exposed to TNF- $\alpha$ which resulted in increased phosphorylation of Ser-32, Ser-36 and Tyr-42 (Fig. 3C, 3D). As described above, both agonist and antagonist modulated the level of TNF- $\alpha$ induced phosphorylation at Ser-32 and Ser-36 on the same pattern. In order to prove that beta-adrenergic receptors stimulation protects HUVECs from apoptosis, via NF- $\kappa \beta$ and IкB $\alpha$ phosphorylation, we blocked NF- $\kappa B$ by the proteosome inhibitor MG132. After inhibition, we again conducted the apoptosis assay, and observed almost similar pattern of apoptosis in HUVECs (Fig. 1E).

\section{Discussion}

In this study, we investigated the effect of beta-adrenergic receptors stimulation on

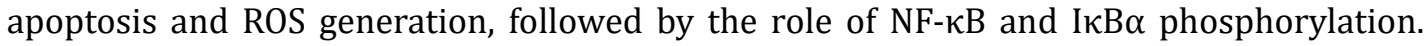
Our data demonstrates that hyperglycaemia could be an apoptotic stimulus which triggers $\mathrm{NF}-\kappa \beta$ release and activation. These mechanisms get halted due to beta-adrenergic receptor stimulation through its agonist isoproterenol. Our data showed a disruption of NF- $\kappa \beta$ pathway through de-phosphorylation which may ultimately lead to reduced apoptosis and low level of ROS generation.

Studies [30] implicate a general dysregulation of the endothelium with apoptosis, mitochondrial dysfunction and increased ROS generation. So we hypothesized that endothelial dysfunction might also be detected in endothelial cells under hyperglycemic conditions which may reflect the degree of apoptosis and increased level of reactive oxygen species [31]. Our results showed reduced ROS generation and decreased apoptosis after beta-adrenergic receptor stimulation. These results are in line with the previous studies $[28,32,33]$ done elsewhere. Studies have also reported that blockade of TNF- $\alpha$ by shRNA and induction of the beta 2 adrenergic receptor by its agonist salmeterol, significantly reduced the apoptosis of retinal Muller cells $[34,35]$. These studies support our findings that demonstrate that beta-adrenergic receptor stimulation increases the cell viability. A recent study, that also support our findings, has reported that activation of the beta- 2 adrenergic receptor could stimulate anti-inflammatory properties of dendritic cells; [36].

To elucidate the observed results, we hypothesized that beta-adrenergic receptors activation shall exert a suppressive effect on NF- $\kappa \beta$ and its inhibitor I $\kappa B \alpha$ as it is well documented that NF- $\kappa B$ plays a key role in modulating the gene expression $[37,38]$. Phosphorylation of NF- $\mathrm{BB}$ p65 at Ser-536 was markedly reduced after beta-adrenergic receptor stimulation. Stimulation of TNF- $\alpha$ further induced the phosphorylation of NF$\kappa B$ p65 at Ser-536, which was reversed by isoproterenol. Our results suggest that betaadrenergic receptors stimulation inhibits the activation of NF- $\mathrm{KB}$ in HUVECs, leading to reduced apoptosis and low level of reactive oxygen species. Increased phosphorylation

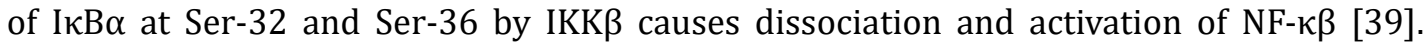

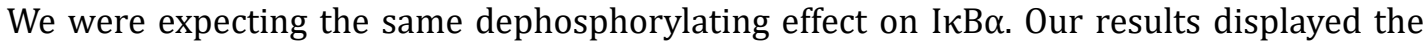
same effect by significantly reducing the phosphorylation of Ser-32 and Ser-36 in glucose and TNF- $\alpha$ induced HUVECs. Furthermore, we observed a reduction in the glucose-induced phosphorylation of Ser-32 and Ser-36 after beta-adrenergic receptor stimulation through isoproterenol. This demonstrates that the anti-apoptotic effect of isoproterenol is possibly due to the suppression of IкB $\alpha$ phosphorylation at Ser-32 and Ser-36 in HUVECs.

\section{Conclusion}

Results of the given study reveal that beta-adrenergic receptors stimulation exert a positive effects by reducing apoptosis and by lowering the level ROS generation. The effect 


\section{Cellular Physiology Cell Physiol Biochem 2018;51:1429-1436

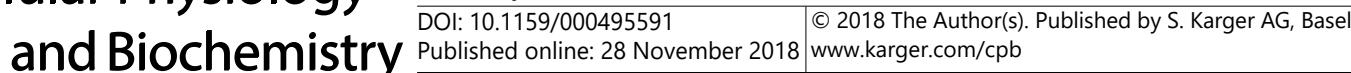 \\ Safi et al.: Beta-AR Stimulation and Phosphorylation of NF-kB and Ikb'B $\alpha$}

of beta-adrenergic receptors agonist appears to be involved in the dephosphorylation of NF$\kappa \beta$ and $\mathrm{I} \kappa \mathrm{B} \alpha$ in hyperglycaemic HUVECs.

\section{Acknowledgements}

This work was supported by UMRG grant no. RG528-13HTM, University of Malaya.

\section{Disclosure Statement}

The authors declare that they have no competing interests.

\section{References}

1 Kolluru GK, Bir SC, Kevil CG: Endothelial dysfunction and diabetes: effects on angiogenesis, vascular remodeling, and wound healing. Int J Vasc Med 2012 doi: 10.1155/2012/918267.

2 Batumalaie K, Safi SZ, Yusof KM, Ismail IS, Sekaran SD, Qvist R: Effect of Gelam Honey on the Oxidative Stress-Induced Signaling Pathways in Pancreatic Hamster Cells. Int J Endocrinol 2013 doi:10.1155/2013/367312.

3 Kumar, S. Safi SZ, Qvist R, Ismail IS: Effect of agonists of adenosine receptors on inflammatory markers in human Muller cells. Current Science 2014;106:582-586.

4 Safi SZ, Batumalaie K, Mansor M, Chinna K, Mohan S, Karimian H, Qvist R, Ashraf MA, Yan GO: Glutamine treatment attenuates hyperglycemia-induced mitochondrial stress and apoptosis in umbilical vein endothelial cells. Clinics (Sao Paulo) 2015;70:569-76 doi: 10.6061/clinics/2015(08)07.

5 Safi SZ, Qvist R, Ong G, Karimian H, Imran M, Shah I: Stimulation of $\beta$-adrenergic receptors plays a protective role via increased expression of RAF-1 and PDX-1 in hyperglycemic rat pancreatic islet (RINm5F) cells. Arch Med Sci 2017;13:470-480 doi: 10.5114/aoms.2016.64131.

-6 Paramasivam D, Safi SZ, Qvis R, Abidin IBZ, Hairi NNM, Chinna K: Role of PPARG (Pro12Ala) in Malaysian type 2 diabetes mellitus patients. Int J Diabetes Dev Ctries 2016;36:449-456.

7 Safi SZ, Shah H, Siok Yan GO, Qvist R: Insulin resistance provides the connection between hepatitis C virus and diabetes. Hepat Mon 2014;15:e23941 doi: 10.5812/hepatmon.23941 eCollection 2015.

8 Wild S, Roglic G, Green A, Sicree R, King H: Global Prevalence of Diabetes: Estimates for the year 2000 and projections for 2030. Diabetes Care 2004;27:1047-1053.

-9 Safi SZ, Qvist R, Chinna K, Ashraf MA, Paramasivam D, Ismail IS: Gene expression profiling of the peripheral blood mononuclear cells of offspring of one type 2 diabetic parent. Int J of Diabetes in Devel Ctries 2015 DOI: $10.1007 / \mathrm{s} 13410-015-0369-1$.

10 Safi SZ, Qvist R, Kumar S, Batumalaie K, Ismail IS: Molecular mechanisms of diabetic retinopathy, general preventive strategies, and novel therapeutic targets. Biomed Res Int 2014 doi: 10.1155/2014/801269.

11 Jansson PA: Endothelial dysfunction in insulin resistance and type 2 diabetes. J Intern Med 2007; 262:173183.

12 Basha B, Samuel SM, Triggle CR, Ding H: Endothelial dysfunction in diabetes mellitus: possible involvement of endoplasmic reticulum stress? Exp Diabetes Res 2012 doi: 10.1155/2012/481840.

$>13$ Safi SZ, Qvist R, Yan GO, Ismail IS: Differential expression and role of hyperglycemia induced oxidative stress in epigenetic regulation of $\beta 1, \beta 2$ and $\beta 3$-adrenergic receptors in retinal endothelial cells. BMC Med Genomics 2014;7:29.

14 Wang XM, Song SS, Xiao H, Gao P, Li XJ, Si LY: Fibroblast growth factor 21 protects against high glucose induced cellular damage and dysfunction of endothelial nitric-oxide synthase in endothelial cells. Cell Physiol Biochem 2014;34:658-671.

15 Avogaro A, Albiero M, Menegazzo L, de Kreutzenberg S, Fadini GP: Endothelial dysfunction in diabetes: the role of reparatory mechanisms. Diabetes Care 2011;34: S285-290.

16 Manna P, Jain SK: Effect of PIP3 on adhesion molecules and adhesion of THP-1 monocytes to HUVEC treated with high glucose. Cell Physiol Biochem 2014;33:1197-1204. 


\section{Cellular Physiology Cell Physiol Biochem 2018;51:1429-1436 \begin{tabular}{l|l|l}
\hline DOI: 10.1159/000495591 & (c) 2018 The Author(s). Published by S. Karger AG, Basel
\end{tabular} and Biochemistry Published online: 28 November 2018 www.karger.com/cpb}

17 Nishikawa T, Edelstein D, Du XL, Yamagishi S, Matsumura T, Kaneda Y, Brownlee M: Normalizing mitochondrial superoxide production blocks three pathways of hyperglycaemic damage. Nature 2000;404:787-790.

18 Li H, Cybulsky MI, Gimbrone MA, Libby P: An atherogenic diet rapidly induces VCAM-1, a cytokineregulatable mononuclear leukocyte adhesion molecule, in rabbit aortic endothelium. Arterioscler Thromb 1993;13:197-204.

19 Lawrence T: The nuclear factor NF-kappaB pathway in inflammation. Cold Spring Harb Perspect Biol 2009;1: a001651.

20 Garg A, Aggarwal BB: Nuclear transcription factor-kappaB as a target for cancer drug development. Leukemia 2002;16:1053-1068.

-21 Ghosh S, May MJ, Kopp EB: NF-kappa B and Rel proteins: evolutionarily conserved mediators of immune responses. Annu Rev Immunol 1999;16:225-260.

-22 Reber L, Vermeulen L, Haegeman G, Frossard N: Ser276 phosphorylation of NF-kB p65 by MSK1 controls SCF expression in inflammation. PLoS One 2009;4:e4393.

23 Wang D, Westerheide SD, Hanson JL, Baldwin AS: Tumor necrosis factor alpha-induced phosphorylation of RelA/p65 on Ser529 is controlled by casein kinase II. J Biol Chem 2000;275:32592-32597.

24 Duran A, Diaz-Meco MT, Moscat J: Essential role of RelA Ser311 phosphorylation by zetaPKC in NF-kappaB transcriptional activation. EMBO J 2003;22:3910-3918.

25 Vermeulen L, De Wilde G, Van Damme P, Vanden Berghe W, Haegeman G: Transcriptional activation of the NF-kappaB p65 subunit by mitogen- and stress-activated protein kinase-1 (MSK1). EMBO J 2003;22:13131324.

26 Zhong H, Voll RE, Ghosh S: Phosphorylation of NF-kappa B p65 by PKA stimulates transcriptional activity by promoting a novel bivalent interaction with the coactivator CBP/p300. Mol Cell 1998;1:661-671.

-27 Sakurai H, Chiba H, Miyoshi H, Sugita T, Toriumi W: IkappaB kinases phosphorylate NF-kappaB p65 subunit on serine 536 in the transactivation domain. J Biol Chem 1999;274:30353-30356.

-28 Walker RJ, Steinle JJ: Role of beta-adrenergic receptors in inflammatory marker expression in Muller cells. Invest Ophthalmol Vis Sci 2007;48:5276-5281.

29 Suleyman H, Halici Z, Cadirci E, Hacimuftuoglu A, Bilen H: Indirect role of beta2-adrenergic receptors in the mechanism of anti-inflammatory action of NSAIDS. J Physiol Pharmacol 2008;59:661-672.

-30 Peters K, Unger RE, Brunner J, Kirkpatrick CJ: Molecular basis of endothelial dysfunction in sepsis. Cardiovasc Res 2003;60:49-57.

31 Gao SS, Shu S, Wang LJ, Zhou J, Yuan ZY: Pro-inflammatory and anti-inflammatory cytokine responses of peripheral blood mononuclear cells in apparently healthy subjects. Nan Fang Yi Ke Da Xue Xue Bao 2014;34:1589-1593.

-32 Walker-Brown J, Roberts MR: Differential contribution of beta-adrenergic receptors expressed on radiosensitive versus radioresistant cells to protection against inflammation and mortality in murine endotoxemia. Shock 2009;32:541-547.

33 Kolmus K, Tavernier J, Gerlo S: beta-Adrenergic receptors in immunity and inflammation: Stressing NFkappaB. Brain Behav Immun 2014 doi: 10.1016/j.bbi.2014.10.007.

-34 Walker RJ, Anderson NM, Jiang Y, Bahouth S, Steinle JJ: Role of beta-adrenergic receptor regulation of TNFalpha and insulin signaling in retinal Muller cells. Invest Ophthalmol Vis Sci 2011;52: 9527-9533.

-35 Zapater P, Gomez-Hurtado I, Peiro G, Gonzalez-Navajas JM, Garcia I, Gimenez P, Frances R: Beta-adrenergic receptor 1 selective antagonism inhibits norepinephrine-mediated TNF-alpha downregulation in experimental liver cirrhosis. PLoS One 2012;7:e43371.

-36 Nijhuis LE, Olivier BJ, Dhawan S, Hilbers FW, Boon L, Wolkers MC, de Jonge WJ: Adrenergic beta2 receptor activation stimulates anti-inflammatory properties of dendritic cells in vitro. PLoS One 2014;9:e85086.

37 Yao J, Hu R, Sun J, Lin B, Zhao L, Sha Y, Guo QL: Oroxylin A prevents inflammation-related tumor through down-regulation of inflammatory gene expression by inhibiting NF-kappaB signaling. Mol Carcinog 2014;53:145-158.

-38 Sakurai H, Chiba H, Miyoshi H, Sugita T, Toriumi W: IkappaB kinases phosphorylate NF-kappaB p65 subunit on serine 536 in the transactivation domain. J Biol Chem 1999;274:30353-30356.

-39 Song Y, Hong J, Liu D, Lin Q Lai G: 1, 25-dihydroxyvitamin D3 inhibits nuclear factor kappa B activation by stabilizing inhibitor IkappaBalpha via mRNA stability and reduced phosphorylation in passively sensitized human airway smooth muscle cells. Scand J Immunol 2013;77:109-116. 